\title{
PENGARUH TINGKAT PENDIDIKAN DAN KEPEMIMPINAN TERHADAP KINERJA ORGANISASI PADA SATUAN KERJA PERANGKAT DAERAH (SKPD) KOTA SOLOK
}

\author{
Yulia Ningsih \\ Universitas Mohammad Natsir Bukittinggi \\ yulia_ningsih@gmail.com
}

\begin{abstract}
This study aimed to reveal the effect of the educational level on organizational performance and the effect of leadership on organizational performance of Local Organization Unit (SKPD) in Solok City. This study was an ex-post facto study. The population of this study was all Local Organization Unit in Solok which in total amounted to 40 units. The sample of this study consisted of 36 Local Organization Units determined through simple random sampling. Data were collected through questionnaire with Likert scale that have been tested their validity and reliability. Then the data were analyzed with multiple regression analysis. The results of this study indicated that: (1) the education level did not significantly influence the organizational performance of Local Organization Unit, and (2) leadership had a significantly influence on the organizational performance of Local Organization Unit in Solok City. This study recommended in terms of public sector policies that the managers of Local Organization Units of Solok City needed to motivate their employees to improve their education to a higher level, providing support to their leaders in implementing the leadership function well in terms of influencing, motivating, directing and guiding employees to perform their jobs well.
\end{abstract}

Keywords: Educational level, leadership, organizational performance

\section{Pendahuluan}

Pemerintah yang bersih dan tata kelola pemerintahan yang baik merupakan isu yang penting dalam pengelolaan administrasi publik. Salah satu upaya untuk melaksanakan penyelenggaraan tata kelola pemerintahan yang baik adalah dengan peningkatan pengetahuan masyarakat, disamping adanya pengaruh dari globalisasi.

Pelaksanaan reformasi di berbagai bidang mengharuskan pemerintah menanggapi tuntutan masyarakat. Salah satu tuntutan dimaksud adalah pelaksanaan otonomi daerah secara luas, nyata dan bertanggung jawab. Semangat reformasi telah mewarnai pandangan aparatur pemerintah. Untuk mewujudkan administrasi negara yang mampu dalam kelancaran dan ketepatan pelaksanaan tugas dan fungsi penyelenggaraan pemerintah dan pembangunan, perlu adanya pemerintahan yang baik dan bersih. Pemerintahan yang baik dan bersih ini ditujukan kepada aparatur pemerintah menyangkut prestasi kerja yang menuntut pemerintah agar memiliki kinerja yang berorientasi pada kepentingan masyarakat 
dengan cara memberikan pelayanan yang berkualitas serta adanya pembagian tugas secara baik pada organisasi pemerintahan tersebut.

Secara umum, kinerja merupakan prestasi yang dicapai oleh organisasi dalam periode tertentu. Kinerja adalah gambaran pencapaian pelaksanaan suatu kegiatan/ program/kebijaksanaan dalam mewujudkan sasaran, tujuan, misi, dan visi organisasi. Pencapaian kinerja yang baik pada masing-masing SKPD tidak lepas dari beberapa faktor. Faktor pertama ialah pengaruh Kualitas Sumber Daya Manusia yang dimiliki SKPD tersebut. Kualitas Sumber Daya Manusia adalah kemampuan sumber daya manusia untuk melaksanakan tugas dan tanggung jawab yang diberikan kepadanya dengan bekal pendidikan, pelatihan, dan pengalaman yang cukup memadai.

Dalam kenyataannya, pada Satuan Kerja Perangkat Daerah (SKPD) Kota Solok masih ditemui beberapa kondisi dari sikap mental, tekad, dan semangat kerja dalam pelaksanaan tugas-tugas yang diberikan belum terlaksana dengan baik. Hal ini terlihat dalam Laporan Akuntabilitas Kinerja Instansi Pemerintah (LAKIP) dimana adanya beberapa tugas belum tercapai sesuai dengan target yang telah ditetapkan. Adapun pekerjaan Satuan Kerja Perangkat Daerah Kota Solok yang belum mencapai target tersebut dapat dilihat pada Tabel 1 berikut ini:

Tabel 1. Pengukuran Kinerja Satuan Kerja Perangkat Daerah Kota Solok Tahun 2014

\begin{tabular}{clc}
\hline No & \multicolumn{1}{c}{ Indikator Kinerja } & $\begin{array}{c}\text { Capaian } \\
\text { Kinerja }\end{array}$ \\
\hline 1. & $\begin{array}{l}\text { Meningkatkan Kualitas Tatanan Kehidupan Masyarakat Yang Beriman } \\
\text { dan Bertaqwa }\end{array}$ & 85,34 \\
2. & Meningkatnya Pengetahuan Pemahaman dan Adat dan & 83,50 \\
3. & Meniningkatnya Kualitas, Disiplin dan Kesejahteraan Aparatur & 76,35 \\
4. & Terwujudnya Pelayanan Publik yang Transparan dan Akuntabel & 85,00 \\
5. & Terwujudnya Perencanaan Pembangunan yang Partisipatif dan & 75,92 \\
& Akuntabel & 73,12 \\
6. & Terwujudnya Pelayanan Kesehatan Yang di Kawasan Sumatera Bagian & \\
7. & Meningkatnya Ketersediaan Prasarana dan Sarana Olah Raga Yang & 75,00 \\
8. & Mepresentatif & 75,83 \\
9. & Tersedianya Prasarana dan Sarana Perdagangan dan Jasa Yang & 22,73 \\
10. & Mepresentatif & 80,10 \\
11. & Meningkatkan Nilai Tambahnya Kualitas Perencanaan, Pemanfaatan dan Pengendalian & 81,68 \\
\hline
\end{tabular}

Sumber: LAKIP Tahun 2014 Satuan Kerja Perangkat Daerah Kota Solok

Berdasarkan Tabel 1 dapat dipahami bahwa masih banyak kinerja Satuan Kerja Perangkat Daerah yang belum mencapai target yang telah ditetapkan. Rendahnya kinerja SKPD ini diduga karena pegawai memiliki kinerja yang 
rendah, sehingga pekerjaan yang dibebankan tidak terlaksana dengan baik. Padahal jika dilihat dari jumlah, pegawai yang ada pada Satuan Kerja Perangkat Daerah Kota Solok sudah cukup memadai.

Bacal (2001) menyatakan bahwa penyebab sukses dan kurang suksesnya organisasi dalam mencapai kinerjanya dapat diklasifikasikan menjadi dua yaitu faktor individual dan faktor sistem. Faktor individual adalah semua faktor yang bersumber dari individu pegawai, termasuk pimpinan; contohnya antara lain adalah memotivasi, komitmen, keahlian, pengetahuan, kemampuan berpikir dan sebagainya. Faktor sistem yaitu semua faktor yang berada dan bersumber di luar kendali para pegawai secara individual; contohnya antara lain prosedur kerja yang baru, organisasi yang gemuk, komunikasi yang jelek, prasarana dan sarana yang kurang memadai, sistem reward, punishment dan sebagainya.

Faktor yang diduga mempengaruhi kinerja SKPD yaitu tingkat pendidikan. Tingkat pendidikan sangat penting bagi setiap organisasi, sehingga perlu dikelola, diatur dan dimanfaatkan agar dapat berfungsi secara produktif untuk mencapai tujuan organisasi. Demikian pula sumber daya manusia yang dimiliki oleh suatu organisasi perlu dikelola secara professional agar terwujud keseimbangan antara kebutuhan pegawai dengan tuntutan dan kemampuan organisasi.

Berbagai fenomena yang ditemukan di SKPD Kota Solok antara lain adalah masih adanya pegawai SKPD yang memiliki tingkat pendidikan yang rendah. Hal ini akan berdampak terhadap kualitas sumber daya manusia yang bekerja pada setiap SKPD yang ada di Kota Solok. Masih ada SKPD Kota Solok yang memiliki pegawai dengan tingkat pendidikan yang rendah terutama tamatan SD dan SMP. Rendahnya tingkat pendidikan akan memberikan dampak yang kurang baik terhadap kinerja organisasi. Hal ini akhirnya tentu akan berpengaruh terhadap kinerja SKPD.

Faktor kedua yang diduga mempengaruhi kinerja yaitu kepemimpinan. Perlu disadari bahwa untuk mengimbangi perubahan-perubahan dan kemajuan dalam berbagai aspek yang mempengaruhi beban kerja pimpinan dituntut tersedianya tenaga kerja yang setiap saat dapat memenuhi kebutuhan. Untuk itu, seseorang pimpinan harus dapat mengelola sumber daya secara efektif dan efesien terutama dalam pengelolaan sumber daya manusia.

Keberhasilan organisasi pemerintah lebih banyak ditentukan oleh keunggulan pemimpinnya. Keunggulan pemimpinnya ditentukan oleh keunggulannnya dalam berkomunikasi dengan seluruh anggota organisasi dan lingkungan dia berada. Oleh karena itu komunikasi pemerintahan merupakan hal yang penting. Pembangunan yang diselenggarakan oleh pemerintah pusat atau daerah akan dapat berhasil jika pemimpin mampu bekomunikasi kepada seluruh anggota dan rakyatnya.

Berdasarkan pengamatan yang dilakukan di SKPD Kota Solok diperoleh informasi mengenai diklat kepemimpinan Kepala SKPD Kota Solok yang menunjukkan bahwa masih banyak pegawai yang belum mengikuti diklat kepemimpinan di SKPD Kota Solok sebanyak 747 orang pegawai. Padahal diklat kepemimpinan sangat penting untuk meningkatkan kinerja SKPD, agar kinerja organisasi dapat tercapai dengan baik. 
Penelitian ini dilakukan untuk mengungkapkan apakah terdapat pengaruh tingkat pendidikan dan kepemimpinan terhadap kinerja organisasi pada Satuan Kerja Perangkat Daerah Kota Solok. Penelitian ini telah dilaksanakan pada tahun 2015.

\section{Tinjauan Kepustakaan}

Menurut Mahsun (2009) kinerja adalah gambaran mengenai tingkat pencapaian pelaksanaan suatu kegiatan/program/kebijakan dalam mewujudkan sasaran, tujuan, misi dan visi organisasi yang tertuang dalam strategic planning. Russel (dalam Ruky, 2006) menyatakan bahwa kinerja adalah catatan tentang hasil-hasil yang diproduksikan dari fungsi-fungsi jabatan atau kegiatan tertentu selama kurun waktu tertentu.

Bacal (2001) menyatakan bahwa penyebab sukses dan kurang suksesnya organisasi dalam mencapai kinerjanya diklasifikan menjadi dua yaitu faktorfaktor individual adalah semua faktor yang bersumber dari individu pegawai termasuk pimpinan sebagai contoh memotivasi, komitmen, keahlian, pengetahuan, kemampuan berpikir dan sebagainya. Faktor-faktor sistem yaitu semua faktor yang berada di luar kendali para pegawai secara individual sebagai contorh prosedur kerja yang baru, organisasi yang gemuk, komunikasi yang jelek, prasarana dan saranan yang kurang memadai, sistem reward, punishment dan sebagainya. Menurut Joedono (2005) faktor-faktor yang mempengaruhi kinerja sebuah organisasi antara lain meliputi 1) faktor kualitas sumber daya manusia, 2) struktur organisasi, 3) teknologi, 4) pimpinan dan masyarakat, 5) bentuk kepemimpinan

Di sisi lain, menurut Hasbullah (2009) pendidikan adalah tuntunan di dalam hidup tumbuhnya anak-anak. Maksudnya adalah bahwa pendidikan menuntun segala kekuatan kodrat yang ada pada anak-anak itu, agar mereka sebagai manusia dan sebagai anggota masyarakat dapatlah mencapai keselamatan dan kebahagiaan yang setinggi-tingginya.

Sementara itu, House (dalam Garry, 2005) menjelaskan pula bahwa kepemimpinan adalah kemampuan individu untuk mempengaruhi, memotivasi dan membuat orang lain mampu memberikan kontribusinya demi efektivitas dan keberhasilan organisasi. Sedangkan menurut Suyonto (2012:34), kepemimpinan adalah kemampuan seseorang untuk menguasai atau mempengaruhi orang lain atau masyarakat yang berbeda-beda menuju pencapaian tertentu.

Selanjutnya Rivai (2004) mengemukakan bahwa secara operasional ada lima fungsi pokok kepemimpinan, yaitu: 1) Fungsi instruksi, fungsi ini bersifat komunikasi satu arah. Pemimpin sebagai communicators merupakan pihak yang menentukan apa, bagaimana, bilamana dan dimana perintah itu dikerjakan agar keputusan dapat dilaksanakan secara efektif: 2) Fungsi konsultasi, fungsi ini bersifat komunikasi dua arah. Dalam menetapkan keputusan pemimpin kerapkali memerlukan bahan pertimbangan, yang mengharuskan ia berkonsultasi dengan orang-orang yang dipimpinnya. 3) Fungsi partisipasi, fungsi ini bersifat bahwa pemimpin berusaha mengaktifkan orang-orang yang dipimpinnya baik dalam keikutsertaan mengambil keputusan maupun dalam melaksanakannya. 4) Fungsi 
delegasi, fungsi ini dilaksanakan dengan memberikan pelimpahan wewenang membuat/menetapkan keputusan baik melalui persetujuan maupun tanpa persetujuan dari pemimpin. 5) Fungsi pengendalian, maksudnya bahwa kepemimpinan yang sukses efektif mampu mengatur aktivitas anggotanya secara terarah dan dalam koordinasi yang efektif, sehingga memungkinkan tercapainya tujuan bersama secara maksimal.

\section{Metode Penelitian}

Penelitian ini tergolong pada penelitian Expost-Facto. Penelitian ini dilaksanakan di Kota Solok. Populasi penelitian ini adalah seluruh pegawai pada Satuan Kerja Perangkat Daerah (SKPD) yang ada di Kota Solok yang keseluruhannya berjumlah 40 SKPD. Teknik pengambilan sampel dilakukan secara bertingkat. Pada tahap pertama sampel ditarik berdasarkan SKPD yang ada di lingkungan pemerintah Kota Solok. Jumlah sampel SKPD dalam penelitian ini ada sebanyak 36 SKPD. Selanjutnya pada masing-masing SKPD diambil 3 orang sebagai responden yang ditentukan dengan menggunakan teknik simple random sampling.

Data penelitian ini diperoleh melalui angket yang diedarkan kepada responden dengan menggunakan skala Likert. Teknik analisa data yang digunakan dalam penelitian ini yaitu analisis deskriptif dengan melihat tingkat capaian responden dan analisis regresi berganda. Selanjutnya dilakukan uji hipotesis dengan menggunakan uji $\mathrm{F}$ dan uji $\mathrm{T}$.

\section{Hasil Penelitian dan Pembahasan}

\section{Uji prasyarat analisis}

Hasil uji normalitas menyatakan nilai Kolmogorov-Smirnov adalah sebesar 0,825 dengan signifikan 0,504 . Berdasarkan hasil tersebut dapat dinyatakan data yang digunakan dalam penelitian ini telah berdistribusi normal dan bisa dilanjutkan untuk dianalisis lebih lanjut, karena nilai signifikan dari uji normalitas $>0,05$. Selanjutnya hasil uji multikolinearitas variabel tingkat pendidikan menunjukkan nilai VIF sebesar 1,092 dan tolerance sebesar 0,916; sedangkan variabel kepemimpinan memiliki nilai VIF sebesar 1,139 dan tolerance sebesar 0,878. Hal ini berarti bahwa nilai VIF (Variance Inflation Faktor) kedua variabel bebas $<10$ dan nilai tolerance $>0,1$. Dengan demikian dapat disimpulkan bahwa tidak terdapat masalah multikolinearitas atau tidak ada hubungan antara sesama variabel bebas yaitu tingkat pendidikan dan kepemimpinan.

Disamping itu, hasil uji heterokedastisitas diperoleh masing-masing skor signifikansi variabel tingkat pendidikan sebesar 0,307 dana variabel kepemimpinan sebesar 0,416. Hal ini berarti skor masing-masing variabel lebih besar dari taraf signifikansi 0,05. Berdasarkan analisis ini dapat disimpulkan bahwa tidak terdapat gejala heterokedastisitas.

\section{Analisis Regresi Linear Berganda}

Analisis regresi linear berganda bertujuan untuk melihat hubungan secara linear antara dua atau lebih variabel independen $\left(\mathrm{X}_{1}, \mathrm{X} 2, \ldots . \mathrm{Xn}\right)$ dengan variabel 
dependen (Y). Dalam penelitian ini yang dilihat adalah pengaruh tingkat pendidikan $\left(\mathrm{X}_{1}\right)$ dan kepemimpinan $\left(\mathrm{X}_{2}\right)$ terhadap kinerja organisasi $(\mathrm{Y})$. Hasil regresi linear berganda dapat dilihat pada Tabel 2 berikut.

\section{Tabel 2. Analisis Regresi Berganda}

\section{Coefficients $^{\mathrm{a}}$}

\begin{tabular}{|c|c|c|c|c|c|}
\hline \multirow[b]{2}{*}{ Model } & \multicolumn{2}{|c|}{$\begin{array}{l}\text { Unstandardized } \\
\text { Coefficients }\end{array}$} & \multirow{2}{*}{$\begin{array}{c}\text { Standardized } \\
\text { Coefficients } \\
\text { Beta }\end{array}$} & \multirow[t]{2}{*}{$\mathbf{t}$} & \multirow[t]{2}{*}{ Sig. } \\
\hline & B & Std. Error & & & \\
\hline (Constant) & -14.217 & 21.158 & & -.672 & .507 \\
\hline $\mathrm{X} 1$ & .849 & .818 & .190 & 1.038 & .307 \\
\hline $\mathrm{X} 2$ & -.109 & .132 & -.154 & -.825 & .416 \\
\hline
\end{tabular}

Berdasarkan tabel 2 diatas dapat diperoleh persamaan regresi linear berganda sebagai berikut:

$$
\begin{aligned}
& \mathrm{Y}=\mathrm{a}+\mathrm{b}_{1} \mathrm{X}_{1}+\mathrm{b}_{2} \mathrm{X}_{2}+\mathrm{e} \\
& \hat{Y}=-52,007+1,690 \mathrm{X}_{1}+0,404 \mathrm{X}_{2}
\end{aligned}
$$

Dari persamaan regresi tersebut diketahui nilai konstanta sebesar -52,007 artinya tanpa adanya variabel tingkat pendidikan $\left(\mathrm{X}_{1}\right)$, kepemimpinan $\left(\mathrm{X}_{\mathrm{s}}\right)$, maka kinerja organisasi adalah $-52,007$. Pengaruh masing-masing variabel bebas yang terdiri dari tingkat pendidikan dan kepemimpinan terhadap variabel terikat yaitu kinerja organisasi adalah sebagai berikut :

(1) Bentuk pengaruh tingkat pendidikan $\left(\mathrm{X}_{1}\right)$ terhadap kinerja organisasi adalah positif sebesar 1,690 dengan nilai $t$ hitung 1,439 (Sig $0,160>0,05$ ), menunjukkan bahwa tingkat pendidikan tidak berpengaruh signifikan terhadap kinerja organisasi.

(2) Bentuk pengaruh kepemimpinan $\left(\mathrm{X}_{2}\right)$ terhadap kinerja organisasi adalah positif sebesar 0,404 dengan nilai $t$ hitung 2,128 (Sig 0,041 < 0,05), menunjukkan bahwa kepemimpinan berpengaruh signifikan terhadap kinerja organisasi Setiap peningkatan kepemimpinan sebesar 1 satuan akan meningkatkan kinerja organisasi sebesar 0,404.

Dengan demikian dapat dikatakan bahwa kepemimpinan berpengaruh positif dan signifikan terhadap kinerja organisasi. Sedangkan tingkat pendidikan berpengaruh positif dan tidak signifikan terhadap kinerja organisasi, dimana semakin tinggi kepemimpinan maka kinerja organisasi akan semakin tinggi.

Selanjutna uji $\mathrm{F}$ dilakukan adalah untuk mengetahui apakah semua variabel bebas yaitu tingkat pendidikan, kepemimpinan, secara bersama-sama memiliki pengaruh yang signifikan terhadap variabel terikat kinerja organisasi SKPD Kota Solok. 
Tabel 3. Uji F

\begin{tabular}{llcrrrr}
\hline \multicolumn{1}{l}{ Model } & \multicolumn{1}{c}{$\begin{array}{c}\text { Sum of } \\
\text { Squares }\end{array}$} & df & Mean Square & \multicolumn{1}{c}{ F } & Sig. \\
\hline 1 & Regression & 1108.678 & 4 & 277.169 & 7.401 & $.000^{\text {a }}$ \\
& Residual & 1160.961 & 31 & 37.450 & & \\
& Total & 2269.639 & 35 & & & \\
\hline
\end{tabular}

Sumber: Pengolahan Data Primer 2015

Dari Tabel 3 di atas dapat diketahui bahwa $F_{\text {hitung }}$ yang terdapat sebesar 7,401 dan $F_{\text {tabel }} 2.68$. Ini menunjukkan $F_{\text {hitung }}>F_{\text {tabel }}(7,401>2.68)$. Dari hasil pengolahan data di atas didapatkan hasil untuk nilai signifikansi hipotesis secara simulan adalah sebesar 0,000 . Hal ini menunjukkan bahwa nilai signifikansi lebih kecil dari 0,05. Dengan demikian hal ini berarti bahwa Ho ditolak dan Ha diterima. Dengan kata lain, tingkat pendidikan dan kepemimpinan berpengaruh terhadap variabel terikat kinerja organisasi SKPD Kota Solok.

Tabel 4. Koefisien Determinan

Model Summary

\begin{tabular}{ccccc}
\hline Model & R & R Square & Adjusted R Square & Std. Error of the Estimate \\
\hline 1 & $.699^{\mathrm{a}}$ & .488 & .422 & 6.11967 \\
\hline
\end{tabular}

a. Predictors: (Constant) X1, X2

Sumber: Pengolahan Data Primer 2015

Selanjutnya koefisien determinasi $\left(\mathrm{R}^{2}\right)$ berguna untuk menunjukkan berapa besar proporsi variabel bebas mampu menjelaskan variabel terikat. Hasil regresi menunjukkan bahwa pengaruh tingkat pendidikan dan kepemimpinan terhadap kinerja organisasi adalah 0,422 dan besarnya sumbangan bersama-sama yang diberikan oleh tingkat pendidikan dan kepemimpinan terhadap kinerja organisasi adalah sebesar $42,2 \%$ dan selebihnya $57,8 \%$ kinerja organisasi ditentukan oleh variabel lain yang tidak terdapat dalam penelitian ini.

Sementara itu, uji t dilakukan untuk melihat secara parsial setiap variabel bebas terhadap variabel terikat. Acuan yang digunakan adalah $t_{\text {hitung }} \geq t_{\text {tabel }}$ atau nilai sig. $\leq 0,05$ maka Ho ditolak dan Ha diterima. Akan tetapi, jika $t_{\text {hitung }}<t_{\text {tabel }}$ atau nilai sig. $\geq 0,05$ maka Ho diterima dan Ha ditolak. Hasil analisis dapat dilihat pada tabel berikut: 
Tabel 5. Uji t

\begin{tabular}{llccccc}
\hline \multirow{2}{*}{ Model } & \multicolumn{2}{c}{$\begin{array}{c}\text { Unstandardized } \\
\text { Coefficients }\end{array}$} & $\begin{array}{c}\text { Standardized } \\
\text { Coefficients }\end{array}$ & \multirow{2}{*}{ t } & \multirow{2}{*}{ Sig. } \\
\cline { 3 - 5 } & & $\mathbf{B}$ & Std. Error & Beta & & \\
\hline 1 & (Constant) & -52.007 & 30.399 & & -1.711 & .097 \\
& X1 & 1.690 & 1.175 & .193 & 1.439 & .160 \\
& X2 & .404 & .190 & .292 & 2.128 & .041 \\
\hline
\end{tabular}

Uji t statistik digunakan untuk menguji besar pengaruh setiap variabel bebas terhadap variabel terikat. Acuan yang digunakan adalah jika $t_{\text {hitung }} \geq t_{\text {tabel }}$ atau nilai sig. $\leq 0,05$ maka Ha ditolak. Akan tetapi, jika $t_{\text {hitung }}<t_{\text {tabel }}$ atau nilai sig. $\geq 0,05$ maka Ha diterima. Hasil analisis dapat digambarkan kesimpulan untuk pengujian hipotesis penilaian sebagai berikut:

Hipotesis pertama yang diajukan yaitu tingkat pendidikan berpengaruh tidak signifikan terhadap kinerja organisasi publik SKPD di Kota Solok. Dari hasil analisis dilihat nilai thitung untuk variabel tingkat pendidikan $\left(\mathrm{X}_{1}\right)$ adalah $1.439<t_{\text {tabel }} 2.03224$ (sig 0,160>0,05), maka Ha ditolak. Dengan demikian, dapat diambil kesimpulan bahwa tingkat pendidikan tidak berpengaruh signifikan terhadap kinerja organisasi.

Hipotesis kedua yang diajukan yaitu kualitas kepemimpinan berpengaruh signifikan terhadap kinerja organisasi publik SKPD di Kota Solok Dari hasil analisis dilihat nilai $t_{\text {hitung }}$ untuk variabel kepmimpinan $\left(\mathrm{X}_{2}\right)$ adalah 2,128 $>\mathrm{t}_{\text {tabel }}$ 2.03224 ( $\operatorname{sig} 0,041<0,05$ ), maka Ha diterima. Dengan demikian, dapat diambil kesimpulan bahwa kepemimpinan berpengaruh signifikan terhadap kinerja organisasi.

Pembahasan hasil penelitian dilakukan berdasarkan hasil analisis baik deskriptif maupun analisis regresi berganda, yang telah diuraikan dalam bentuk deskripsi variabel-variabel penelitian serta analisis hasil penelitian tentang pengaruh variabel penyebab terhadap variabel akibat.

\section{Pengaruh Tingkat pendidikan terhadap Kinerja Organisasi SKPD Kota Solok}

Berdasarkan hasil pengujian hipotesis diperoleh bahwa tingkat pendidikan tidak berpengaruh signifikan terhadap kinerja organisasi SKPD Kota Solok. Hal ini menunjukkan bahwa tingkat pendidikan belum sesuai dengan harapan sehingga masih ada di sebagian SKPD memiliki kualitas yang rendah atau di bawah tingkat pendidikan sarjana.

Menurut Joedono (2005) faktor-faktor yang mempengaruhi kinerja sebuah organisasi antara lain meliputi 1) faktor tingkat pendidikan, 2) struktur organisasi, 3) teknologi, 4) pimpinan dan masyarakat, 5) bentuk kepemimpinan. Tingkat pendidikan mempunyai peran utama dalam setiap kegiatan organisasi. Dengan didukung oleh sumber daya manusia yang handal, kegiatan organisasi akan terselesaikan dengan baik. Hal ini menunjukkan bahwa tingkat pendidikan merupakan kunci pokok yang harus diperhatikan dengan segala kebutuhannya. 
Namun untuk kasus di SKPD Kota Solok terlihat bahwa tingkat pendidikan tidak memiliki pengaruh signifikan terhadap kinerja organisasi.

\section{Pengaruh Kepemimpinan terhadap Kinerja Organisasi SKPD Kota Solok}

Hasil pengujian hipotesis diketahui bahwa kepemimpinan berpengaruh signifikan terhadap kinerja SKPD Kota Solok. Hal ini berarti semakin baik kepemimpinan, maka semakin tinggi kinerja SKPD Kota. Hasil penelitian deskriptif menunjukkan bahwa secara keseluruhan kepemimpinan SKPD sudah termasuk baik. Hal ini disebabkan karena pimpinan telah menerapkan fungsi kepemimpinan seperti mempengaruhi, memotivasi, mengarahkan dan membimbing pegawai dalam melaksanakan pekerjaan dengan baik sehingga berdampak terhadap kenaikan terhadap kinerja organisasi.

Hasil penelitian sejalan dengan pendapat Joedono (2005) manyatakan bahwa faktor-faktor yang mempengaruhi kinerja sebuah organisasi antara lain meliputi 1) faktor kualitas sumber daya manusia, 2) struktur organisasi, 3) teknologi, 4) pimpinan dan masyarakat, 5) bentuk kepemimpinan. Hasil penelitian ini mendukung hasil penelitian Nurwati (2012) yang menyatakan bahwa kepemimpinan yang baik dapat meningkatkan kinerja pegawai denga mempertimbangkan factor-faktor seperti budaya organisasi, komitmen pekerjaan dan perilaku bekerja di SKPD di provinsi Sulawesi Tenggara. Marbawi (2010) juga menemukan bahwa secara simultan variabel partisipasi anggaran, gaya kepemimpinan maupun komitmen organisasi berpengaruh signifikan terhadap kinerja manajerial pada SKPD Kota Lhokseumawe.

\section{Penutup}

Berdasarkan hasil analisis dan pembahasan pada uraian sebelumnya dapat disimpulkan bahwa:

1) Tingkat pendidikan tidak berpengaruh terhadap kinerja organisasi di SKPD Kota Solok. Artinya semakin berkualitas Sumber daya manusia pada masingmasing SKPD Kota Solok, belum tentu dapat meningkatkan kinerja organisasi. Dimana terjadinya kesenjangan tingkat pendidikan pada masingmasing SKPD.

2) Kepemimpinan berpengaruh terhadap kinerja organisasi di SKPD Kota Solok. Artinya kinerja organisasi dapat ditingkatkan dengan cara pemimpin pada SKPD Kota Solok melaksanakan fungsi kepemimpinan dengan baik.

Dalam upaya meningkatkan kinerja SKPD Kota Solok maka saran yang dapat disampaikan dari hasil penelitian ini adalah sebagai berikut:

1) Upaya yang perlu dilakukan terkait tingkat pendidikan adalah pimpinan SKPD memberikan kesempatan kepada pegawai untuk melanjutkan tingkat pendidikan dan/atau memberikan pelatihan kepada pegawai.

2) Upaya yang perlu dilakukan terkait kepemimpinan adalah agar pimpinan selalu berusaha mempengaruhi bawahan supaya melaksakan pekerjaan sesuai dengan prosedur yang telah ditetapkan; pimpinan hendaknya memberikan pembinaan kepada pegawai dalam melaksanakan pekerjaan; pimpinan perlu 
memberikan penghargaan dan pujian kepada pegawai dalam melaksanakan pekerjaan; dan pimpinan perlu mengarahkan pegawai dalam melaksanakan pekerjaan dengan tepat waktu.

\section{DAFTAR KEPUSTAKAAN}

Bacal, Robert. (2001). Performance Management. Jakarta: PT. Gramedia Pustaka Utama.

Garry, Yuk1. (2005). Kepemimpinan dalam Organisasi. Edisi kelima. Jakarta: Indeks

Hasbullah. (2009). Dasar-dasar Ilmu Pendidikan Edisi Revisi. Jakarta: Rajawali Pers.

Joedono. (2005). "Pengaruh Budaya Organsiasi Terhadap Kinerja Organisasi dan Kepuasan Kerja Karyawan Pada Terminal Penumpang Umum di Surabaya". Jurnal Manajemen \& Kewirausahaan. Vol 7. No. 1 Maret 2005.

Mahsun, Mohammad. (2009). Pengukuran Kinerja Sektor Publik. Yogyakarta: BPFE Yogyakarta.

Marbawi, Adamy. (2010). "Pengaruh Kepemimpinan dan Komitmen Organisasi Terhadap Kinerja Manjerial pada SKPD Kota Lhokseumawe". Journal Aplikasi Manajemen Volume 8 Nomor 4 Nopember 2010.

Nurwati. (2012). "Pengaruh Kepemimpinan terhadap Budaya Organisasi, Komitmen Kerja, Perilaku Kerja dan Kinerja Pegawai”. Jurnal Aplikasi Menajemen. Volume 10 Nomor 1 Maret 2012.

Rivai, Veithzal. (2004). Manajemen Sumber Daya Manusia Untuk Perusahaan. Jakarta: PT. Rajagrafindo Persada.

Ruky, Achmad, S. (2006). Sistem Manajemen Kinerja. Jakarta PT. Sun.

Suyonto, Danang. (2012). Sumber Daya Manusia; Teori, Kuesioner dan Analisis Data. Yogyakarta: CAPS (Center fo Academic Publishing Service) 